\title{
STRUCTURE OF THE PASSIVE SIDE OF A BANK'S BALANCE SHEET VERSUS THE PARI PASSU AND NO-CREDITOR-WORSE-OFF RULES
}

\section{Magdalena Kozińska}

SGH Warsaw School of Economics, Warsaw, Poland

e-mail: mkozin@sgh.waw.pl

ORCID: 0000-0001-8767-6545

\section{(C) 2018 Magdalena Kozińska}

This is an open access article distributed under the Creative Commons Attribution-NonCommercial-NoDerivs license (http://creativecommons.org/licenses/by-nc-nd/3.0/)

DOI: $10.15611 /$ fins.2018.3.07

JEL Classification: G01, G18, G21, G28, G32, G33, H12

\begin{abstract}
The passive side of a bank's balance sheet is characterized by considerable variety. Additionally, the intention of the supervisors is that the bank losses are covered according to a specific order, which foresees that the owners are the first to be exposed, followed by the creditors (but some of the bank's liabilities are essential for the continuation of the operations and it is not recommended that they are redeemed or converted into shares). The sequence of covering losses expected in the supervisory regulations is often inconsistent with the order resulting from the hierarchy of claims established in the bankruptcy law. In such a situation, implementing actions involving the write-down or conversion into shares of subsequent categories of debt may entail breaking the basic principles of bankruptcy and resolution law: the pari passu and no-creditor-worse-off rules. The purpose of the article is to identify situations in which the indicated rules are breached, as well as to review and evaluate national solutions that have been implemented to ensure compliance with the above mentioned rules. To this end, the relationship between the structure of the passive side of the bank balance sheet, supervisory regulations in the area of capital adequacy and the resolution principles were analyzed. As a result, four situations have been identified where there is a risk of breaking the already mentioned rules. The review of national solutions implemented to address the problem suggests that they lead mainly to its shift to the next category in the claims' hierarchy, but does not eliminate it. A similar effect is also provided by the amendment of the BRR Directive, which aims mainly to harmonize solutions introduced at national level.
\end{abstract}

Keywords: bank capital, own funds, pari passu, no-creditor-worse-off, hierarchy of claims. 


\section{Introduction}

A distinctive feature of banking activity is high leverage, which results from the domination of foreign sources of financing (mainly deposits, but also, for example, bonds). Own capital, although significantly strengthened in recent years ${ }^{1}$, accounts for the smaller share in the banks' balance sheet total. Nevertheless, equity constitutes an essential (and first) source of financing the losses. Share capital (together with other instruments classified as Common Equity Tier 1 capital) is a category, which - from the point of view of a banks' stability - ensures funds for covering the losses resulting from current, on-going operations. At the same time, charging the banks' shareholders is a relatively transparent and uncontroversial mechanism. Nonetheless, it often happens that the amount of a bank's equity is insufficient to cover its losses (this is usually the case when the bank has started the procedure of restructuring and orderly liquidation, the so-called resolution) and it is necessary to also make the bank's creditors financially accountable for the bank's activities. Such a solution usually raises many objections, since the influence of creditors on the bank is limited. In addition, the diversity of the functions of the bank's liabilities frequently raises doubts as regards the economic justification for their redemption (e.g. the claims of depositors who entrust their savings to the bank). Therefore in most national legal frameworks there are hierarchies of claims (often adapted to the characteristics of banks), which determine the order of charging shareholders and creditors the losses. Nevertheless, several types of banks' liabilities, which play different roles and are treated diversely by the supervisor (since they result from e.g. financing or hedging operations), may sometimes be assigned to one category of claims.

The aim of the article is to analyze the relationship between the structure of bank liabilities, the hierarchy of claims and the effectiveness (irrevocability) of the intervention measures towards a bank threatened with bankruptcy (i.e. at the resolution stage), as well as a review of the national solutions aimed at reducing the barriers identified in practice.

To this end, a brief description of the structure of a bank's liabilities and the sequence of covering losses by bank stakeholders in accordance with the reverse order of claims hierarchy were carried out. Next, a synthetic depiction of the topic of the claims hierarchy, its relation to banking and (as a result of interactions between the indicated areas) the risk of violating the basic rules of bankruptcy law in the resolution process (pari passu and no-creditor-worse-off, NCWO, rules) ${ }^{2}$ was conducted. The

\footnotetext{
${ }^{1}$ This is evidenced by the observations of the European Banking Authority (EBA) and the results of its stress tests. According to the information provided in the publication about the outcome of the latest survey on bank resilience for shock scenarios, from 2011 to the end of 2015, the average capital base of banks in the European Union (EU) increased by over 4 percentage points. Source: EBA, 2016 EU-WIDE STRESS TEST, http://www.eba.europa.eu/documents/10180/1532819/2016-EU-widestress-test-Results.pdf (accessed on 13.11.2017).

${ }^{2}$ These rules will be described later in the article.
} 
second part of the article presents an overview of national and European solutions aimed at reducing the identified risks. The discourse is completed with conclusions for more optimal banking sector regulations.

\section{Structure of a bank's passive side of balance sheets}

The basic category of the passive side of a bank's balance sheet are its own funds ${ }^{3}$. However, this category is quite differentiated and divided into three subcategories:

1. Common Equity Tier I (CET1).

2. Additional Tier 1 Capital (AT1).

3. Tier 2 Capital (T2).

The division into the abovementioned categories results from the regulations regarding bank capital adequacy, for which the binding legal basis in the European Union (EU) is CRR Regulation ${ }^{4}$.

Tier 1 core capital consists mainly of the ownership instruments 5 . However, their strong diversity within the EU is visible. The inclusion of the instrument in the calculation of own funds is conditioned by the earlier acknowledgement by the EBA, which maintains a list of accepted securities. According to the latest breakdown prepared by the authority, this list $^{6}$ embraces 130 different instruments (mainly various kinds of shares), 30 of which are being gradually excluded from the calculation (i.e. are covered by the so-called grandfathering). The largest diversity of instruments is characteristic for Germany (17 different securities), the smallest - for Bulgaria, Estonia, Slovenia and Slovakia (1 in each country). A concise summary of the number of CET1 instruments accepted in each Member State is included in the table below.

According to the World Bank, on a global scale the average share of banks' equity (in different forms) in their assets is slightly over $10 \%{ }^{7}$. The remaining part, almost $90 \%$, are foreign sources of financing. Some of them are included in the calculation of the bank's own funds, i.e. AT1 and T2. They take the form of debt instruments whose features are presented in the table below. At the same time for banks operating

\footnotetext{
${ }^{3}$ It should be emphasized that the notion of own funds is not equal to the notion of equity. The concept of own funds is usually broader, as it also includes (in addition to equity instruments that are usually own capital) debt instruments that fulfill specific features.

${ }^{4}$ Regulation (EU) No 575/2013 of the European Parliament and of the Council of 26 June 2013 on prudential requirements for credit institutions and investment firms, amending Regulation (EU) No. 648/2012.

${ }^{5}$ Additionally, CET1 includes also, among others, share premiums, profits from the current reporting period, retained earnings and general bank risk funds.

${ }^{6}$ The most recent list of ownership instruments recognized by the EBA in the calculation of own funds was published in May 2017 and is available on the website of the authority: http://www.eba. europa.eu/regulation-and-policy/own-funds (accessed on 14.11.2017).

7 Source: data as of the end of 2015, https://data.worldbank.org/indicator/FB.BNK.CAPA. ZS?end $=2016 \&$ start $=2010$ (accessed on 14.11.2017).
} 
Table 1. Number of financial instruments classified by the EBA as eligible to CET1 in each Member State

\begin{tabular}{|l|c|l|c|}
\hline \multicolumn{1}{|c|}{ Member State } & $\begin{array}{c}\text { Number of CET1 } \\
\text { instruments }\end{array}$ & \multicolumn{1}{|c|}{ Member State } & $\begin{array}{c}\text { Number of CET1 } \\
\text { instruments }\end{array}$ \\
\hline Austria & 14 & Italy & 5 \\
\hline Belgium & 4 & Latvia & 2 \\
\hline Bulgaria & 1 & Lithuania & 3 \\
\hline Croatia & 3 & Luxemburg & 7 \\
\hline Cyprus & 2 & Malta & 3 \\
\hline Czech Republic & 4 & Poland & 5 \\
\hline Denmark & 3 & Portugal & 7 \\
\hline Estonia & 1 & Romania & 3 \\
\hline Finland & 6 & Slovakia & 1 \\
\hline France & 10 & Slovenia & 4 \\
\hline Germany & 17 & Spain & 3 \\
\hline Greece & 5 & Sweden & 2 \\
\hline Hungary & 2 & Netherlands & 7 \\
\hline Ireland & 5 & Great Britain & \\
\hline
\end{tabular}

Source: own work based on the data from EBA.

Table 2. Characteristics of AT1 and T2 instruments

\begin{tabular}{|c|c|c|c|}
\hline \multicolumn{2}{|c|}{ Criterion of comparison } & AT1 & T2 \\
\hline \multicolumn{2}{|c|}{ Minimum maturity } & $\begin{array}{l}\text { Perpetual (option to redeem no } \\
\text { earlier than after } 5 \text { years) }\end{array}$ & 10 years \\
\hline \multicolumn{2}{|c|}{ Cancellation of the coupon } & Fully optional & Not applicable \\
\hline \multicolumn{2}{|c|}{ Subordination } & $\begin{array}{l}\text { Subordinated (senior to CET1) } \\
\text { (junior subordinated) }\end{array}$ & $\begin{array}{l}\text { Subordinated (senior to AT1) } \\
\text { (senior subordinated) }\end{array}$ \\
\hline \multirow[b]{2}{*}{$\begin{array}{l}\text { Possibility } \\
\text { to use the } \\
\text { instrument to } \\
\text { loss absorption } \\
\text { during normal } \\
\text { business activity }\end{array}$} & Activation & CET $1<5,125 \%$ & Not applicable \\
\hline & Mechanism & $\begin{array}{l}\text { Temporary write-down } \\
\text { Permanent write-down } \\
\text { Conversion to shares }\end{array}$ & Not applicable \\
\hline \multirow{2}{*}{$\begin{array}{l}\text { Possibility } \\
\text { to use the } \\
\text { instrument to } \\
\text { loss absorption } \\
\text { in liquidation }\end{array}$} & Activation & $\begin{array}{l}\text { Positive assessment of the } \\
\text { conditions activating the } \\
\text { resolution or declaration of the } \\
\text { bankruptcy }\end{array}$ & $\begin{array}{l}\text { Positive assessment of the } \\
\text { conditions regarding the } \\
\text { resolution or declaration of } \\
\text { the bankruptcy }\end{array}$ \\
\hline & Mechanism & $\begin{array}{l}\text { Permanent write-down or } \\
\text { conversion to shares }\end{array}$ & $\begin{array}{l}\text { Permanent write-down or } \\
\text { conversion to shares }\end{array}$ \\
\hline
\end{tabular}

Source: own work based on CCR Regulation. 
in the EU, the average value of the sum of CET1, AT1 and T2 instruments to riskweight assets is approximately $18.2 \%$.

In addition to the debt classified as AT1 or T2, banks may also issue other forms of liabilities not included in the calculation of own funds but counted towards the MREL $^{9}$ or TLAC ${ }^{10}$ requirement. In the European legal framework they are called "eligible liabilities" and have to meet several conditions. The most important of them are a residual maturity is of at least one year, and the liability does not result from a derivative or deposit. For the TLAC requirement it is necessary that the liabilities are also subordinated to the liabilities excluded from the TLAC calculation (the so-called subordination requirement ${ }^{11}$ ). The preconditions set for liabilities to be qualified as eligible liabilities are therefore significantly less restrictive than for CET1, AT1 and T2.

Moreover, banks may finance their operations through the issuances of instruments that are not considered as part of any supervisory requirements (e.g. covered bonds, structured instruments or derivatives). In the case of the majority of banks, obtaining deposits is the key source of raising funds for their operations. The share of deposits in the assets of banks operating in the EU is shown in the chart below.

As results from the abovementioned concise overview of possible sources of financing the bank's operations, both capital and liabilities are characterized by a significant variety. From the supervisory point of view, the structure of the passive side of a bank's balance sheet should, however, allow absorbing potential losses in accordance with the sequence shown in the diagram below. This order foresees charging with bank losses the holders of the instruments included in the subsequent, broadly defined categories of capital or liabilities. However, the diversity of securities

\footnotetext{
${ }^{8}$ Source: Statistical Data Warehouse, European Central Bank (accessed on 17.11.2017).

${ }^{9}$ MREL is a requirement for own funds and eligible liabilities, the fulfillment of which is to ensure that the resolution authority has the possibility to apply the bail-in tool to cover the bank's losses in case of its bankruptcy (or near bankruptcy). It is determined individually for each bank by the resolution authority. More about the MREL requirement can be found in: O. Szczepańska, MREL and TLAC i.e. how to increase the loss absorption capacity of banks, Bezpieczny Bank 3(60)/2015, pp. 41-47.

${ }^{10}$ TLAC is the requirement for the bank to have an adequate amount of own funds and a certain minimum amount of debt (subordinated) liabilities that are to ensure the possibility to apply a bail-in tool. Its level has been determined by the Financial Stability Board (FSB) and amounts to a min. 18\% of risk-weighted assets and $6.75 \%$ of the bank's total exposure. The requirement is applicable towards global systemically important banks. This means that the TLAC requirement is convergent with the MREL. Differences exist only in the technical details of their determination and maintenance. More about the TLAC requirement in: O. Szczepańska, MREL and TLAC..., op. cit.

${ }^{11}$ The introduction of such a requirement with regard to the MREL is currently being discussed on the EU forum: Proposal for a DIRECTIVE OF THE EUROPEAN PARLIAMENT AND OF THE COUNCIL amending Directive 2014/59/EU on loss-absorbing and recapitalisation capacity of credit institutions and investment firms and amending Directive 98/26/EC, Directive 2002/47/EC, Directive 2012/30/EU, Directive 2011/35/EU, Directive 2005/56/EC, Directive 2004/25/EC and Directive 2007/36/EC.
} 


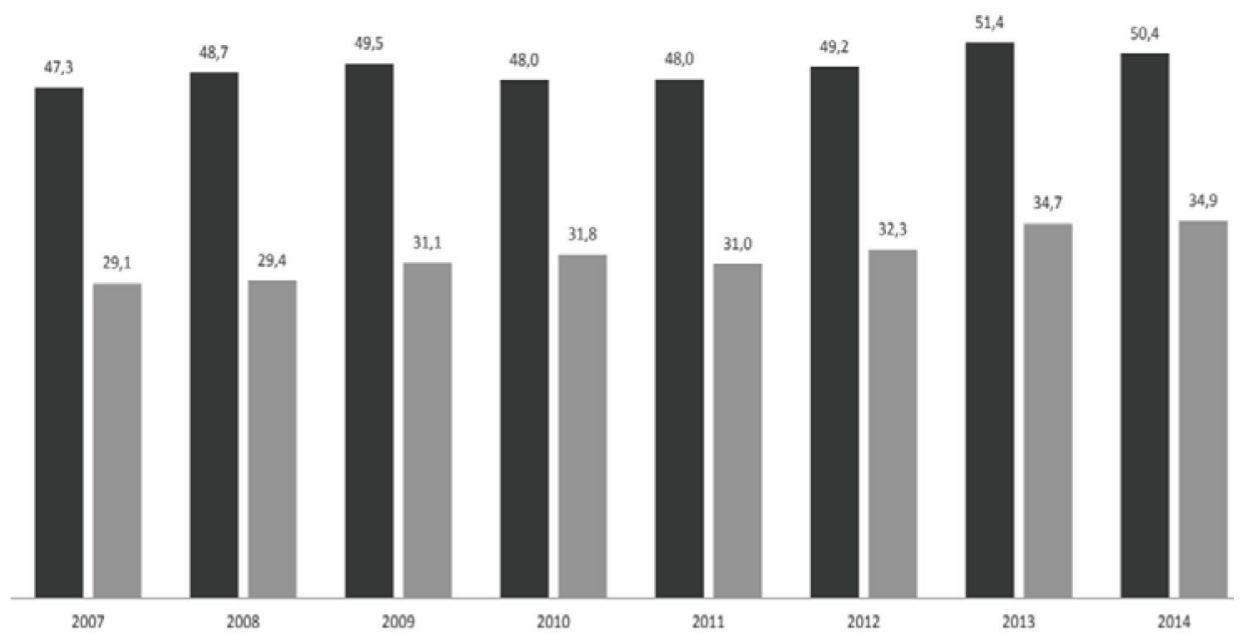

Fig. 1. The ratio of deposits to total assets in EU banks

Key: black indicates the share of total deposits in total assets, gray indicates the share of deposits of non-financial institutions in total assets.

Source: European Banking Federation, European Banking Sector Facts \& Figures 2015, http://www. zyyne.com/zh5/187540\#p=14 (accessed on 15.11.2017).

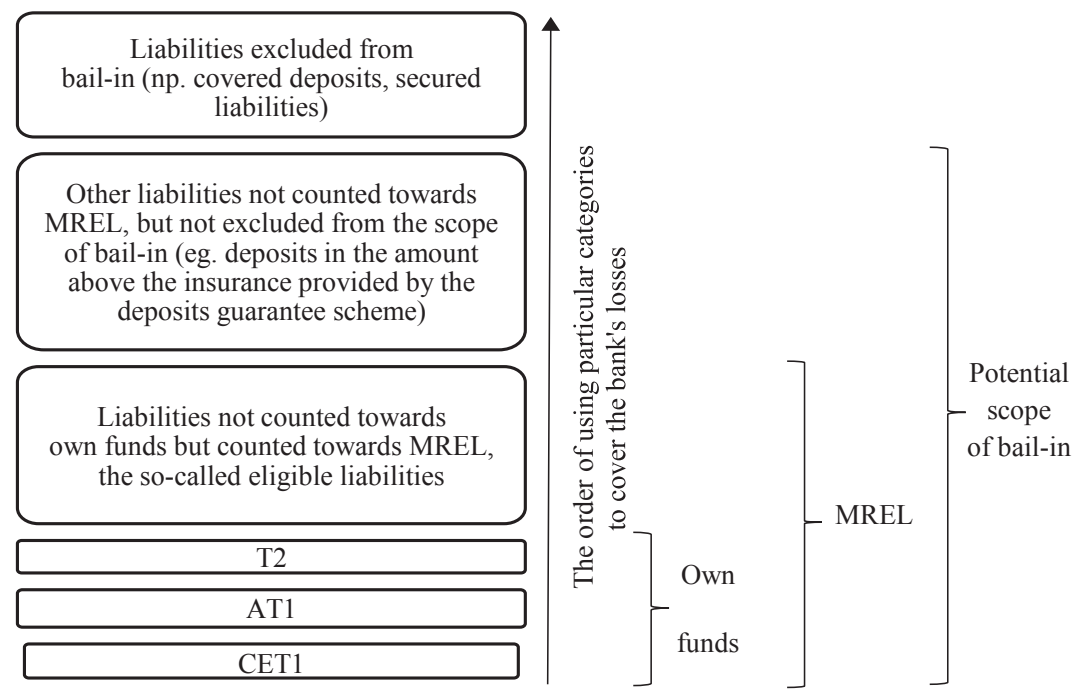

Fig. 2. Supervisory categories of banks' capital and liabilities in the order of covering a bank's losses Source: own word based on: CRR Regulation, BRR Directive and proposals for their amendment. 
eligible for each of them is significant (which is associated with the wide range of banks' funding sources).

In relation to the particular forms of banks' capital or liabilities, it is worth emphasizing that their categories have been designed to cover bank losses at two separate stages, i.e.:

- during normal business activity (going-concern),

- in the event of insolvency / bankruptcy (gone-concern).

Table 3. Division of bank funds and liabilities depending on the nature in covering bank losses

\begin{tabular}{|l|l|l|}
\hline \multicolumn{1}{|c|}{ Stage } & \multicolumn{1}{|c|}{ Purpose } & \multicolumn{1}{c|}{$\begin{array}{c}\text { Examples of balance } \\
\text { sheet items }\end{array}$} \\
\hline Going concern & $\begin{array}{l}\text { Coverage of ongoing losses } \\
\text { resulting from the business }\end{array}$ & $\begin{array}{l}\text { CET1 } \\
\text { AT1 }\end{array}$ \\
\hline Gone concern & $\begin{array}{l}\text { Coverage of bank losses in the } \\
\text { event of insolvency / bankruptcy } \\
\text { (via redemption or conversion } \\
\text { possible under the powers of } \\
\text { the resolution authority or in the } \\
\text { event of liquidation) }\end{array}$ & $\begin{array}{l}\text { T2 } \\
\text { Liabilities not included in } \\
\text { own funds (e.g. eligible } \\
\text { liabilities) } \\
\text { Deposits above the guarantee } \\
\text { level }\end{array}$ \\
\hline
\end{tabular}

Source: own work.

\section{Hierarchy of claims}

As presented in the previous paragraph of the article, the expectation of the regulators in the field of capital adequacy and crisis management is that subsequent categories of instruments issued by banks participate in covering their losses in a strictly defined order. However, this solution is not always consistent with applicable bankruptcy law in particular countries.

The bankruptcy law of each country determines the order of satisfying the claims of particular creditors' groups of the failing entity, establishing a hierarchy of claims which determines the categories of instruments with different levels of subordina-tion/preference.

Many countries have adjusted the claims hierarchies to the characteristics of the banking activity (by including at least categories of claims which result from CET1, AT1, T2 instruments). However, this is not the rule. For example, in countries such as Cyprus, Estonia, Finland, France, Ireland, Latvia, Lithuania and Luxembourg, the hierarchies of claims do not refer to typically bank categories regarding capital adequacy or orderly liquidation. In other countries, including Poland, the hierarchy of claims is adapted to the specificities of banking operations in such a way that a separate sequence of satisfying bank claims has been established (e.g. CET1) ${ }^{12}$.

${ }^{12}$ Article 440 of the Act of 28 February 2003 r. Bankruptcy law (Dz.U.2016.2171 with later changes). 


\begin{tabular}{|c|c|c|}
\hline \multirow[b]{3}{*}{ Rising level of seniority } & Share capital $\quad--------\rightarrow$ & \multirow[t]{6}{*}{ first used to cover losses } \\
\hline & Subordinated debt (junior) & \\
\hline & Preference debt (senior) & \\
\hline \multirow{3}{*}{ first satisfied claims } & Secured liabilities & \\
\hline & Guaranted deposits & \\
\hline & State claims & \\
\hline \multicolumn{3}{|c|}{$\begin{array}{l}\text { * The division presented above is only illustrative. In each country, the number of existing } \\
\text { categories may be higher, i.e. there may be a greater number of classes and they may have a more } \\
\text { specific character. }\end{array}$} \\
\hline
\end{tabular}

Fig. 3. Hierarchy of claims - an overview

Source: own work based on: A. Machowska (red.), Prawo restrukturyzacyjne i upadtościowe. Zagadnienia praktyczne [Restructuring and bankruptcy law. Practical issues], Wolters Kluwer, Warszawa, 2016, pp. 270-383.

Simultaneously, in Italy and Slovakia, holders of securities classified as CET1 and AT1 are treated equally in the event of bankruptcy, i.e. they are included in the same preference group ${ }^{13}$.

The abovementioned issues mean that the supervisory order of covering the losses in the event of bankruptcy does not coincide with that which results from the hierarchy of claims in bankruptcy law, therefore there is a risk that the following situations may occur:

- Situation 1 [Two supervisory categories - two instruments in one category in the claims' hierarchy]: The resolution authority decides that it is sufficient for losses to be covered by one (first) category of instruments (CET1), while, according to the insolvency law, also other instruments (e.g. AT1) are in the same priority group. This means that the CET1 holders suffered higher losses than in the case of hypothetical bankruptcy (then the losses would be divided among all holders of instruments included in a given seniority group).

- Situation 2 [Two supervisory categories - one instrument according to the hierarchy of claims]: The resolution authority decides that losses will be covered by all instruments included in CET1, AT1 and T2. Instruments with features that would qualify them for T2 capital were not fully included in the calculation of own funds. This means that instruments with the same characteristics (and to the

13 Annex 3 - Insolvency Ranking in the jurisdictions of the Banking Union, https://srb.europa. eu/sites/srbsite/files/ldr_-_annex_on_insolvency_ranking_13_02_2017_final.pdf (accessed on 15.11.2017). 
same seniority under bankruptcy law) were partially included in T2 capital, and in part not. However, only the instruments classified as T2 capital were burdened with losses, although according to bankruptcy law they should have been treated in the same way.

- Situation 3 [One category in the hierarchy of claims - a few instruments]: The resolution authority decides that due to the level of losses they will be covered by the holders of instruments classified as CET1, AT1, T2 and, subsequently, by - holders of senior (unsecured) debt (the so-called vanilla senior debt). However, in bankruptcy law this has the same level of seniority as, for example, structured instruments and corporate deposits. Therefore, as part of the resolution, it incurred higher losses than would have been incurred if the bank was liquidated as under the standard bankruptcy proceedings.

- Situation 4 [One category in the claims' hierarchy - several instruments, including those excluded from bail-in]: The resolution authority decides that the losses of the bank should be covered by holders of CET1, AT1, T2 and senior debt. This debt is included in the hierarchy of claims to the same group, in which there are liabilities resulting, for example, from renting a building in which the bank's head office is located. However, these liabilities are excluded from the bail-in. This means that from the point of view of bankruptcy law, bank creditors classified in the same category in the hierarchy of claims have been treated in a different way.

The situations identified above are examples of a possible breach of the pari passu and no-creditor-worse-off rules (the consequences of which may be the necessity to pay damages to bank creditors) which they will be characterized in the next section. However, the indicated problems would not exist if all supervisory categories (or regarding orderly liquidation) were identical with those from the claims' hierarchy. This problem is particularly evident in relation to liabilities falling under the MREL requirement. Their subordination to the bank's remaining liabilities ensures that within the MREL, the resolution authority has a reliable and effective source of financing the losses of the bank. The lack of appropriate regulations results in the risk that the MREL will not be an indisputable source of financing for the resolution.

\section{Pari passu and NCWO rules - the risk of breaching them in resolution}

The pari passu and no-creditor-worse-off (NCWO) rules are the basic principles applicable in bankruptcy law as well as in the resolution of banks.

The pari passu principle means that the creditors who, according to the hierarchy of claims, belong to the same group, should be treated in the same way. According to this rule, holders of instruments belonging to one category of seniority should be burdened with losses equally ${ }^{14}$.

${ }^{14}$ A. Machowska (red.), Prawo restrukturyzacyjne i upadłościowe. Zagadnienia praktyczne [Restructuring and bankruptcy law. Practical issues], Wolters Kluwer, Warszawa 2016, p. 321. 
The no-creditor-worse-off principle means, in turn, that as part of the interventions towards the bank, holders of particular instruments should not end up in a worse position than if standard bankruptcy proceedings had been applied. This is tantamount to the fact that the bank's creditors should not, as a result of the resolution action, suffer higher losses than the losses they would have suffered in the event of the bank's bankruptcy ${ }^{15}$.

Breaking the abovementioned rules means that the holders of financial instruments, who have been exposed to higher losses as a result of the resolution authority's actions, may apply for compensation paid by the resolution authority from the resolution fund. Breaching the rules occurs in each case identified in the previous paragraph of the article. Such situations jeopardize the effectiveness of interventions, because it undermines their reliability.

This problem has been partially identified by some EU Member States. In response to the abovementioned challenges, they introduced (or plan to introduce) modifications of the national bankruptcy laws in such a way that the actions undertaken in the course of resolution would not violate the basic principles adopted not only in the doctrine of bankruptcy law, but also in the principles of resolution execution specified in the BRR Directive.

\section{Solutions proposed in some EU Member States}

The group of countries in which reforms of the hierarchy of claims were undertaken includes Belgium, France, Spain, Germany and Italy. An approach to the problem of subordination was also developed in Great Britain. The difference in the case of the last indicated country (in comparison to the previously listed) consists in the stronger emphasis on structural subordination. The previously mentioned countries decided to introduce statutory or contractual subordination of claims. In this part of the article, the solutions applied by particular countries will be characterized.

Many countries, at least partially to solve the problem of breaking the pari passu and NCWO rules in resolution, decided to create a new, additional class of claims' hierarchy. Instruments included in the new class of claims are usually senior to at least the instruments classified as T2 capital, but at the same time subordinated to those financial instruments to which they currently have the same category in accordance with the national bankruptcy law. By definition, instruments issued for the purpose of being counted towards eligible liabilities are to be included in the newly established category of claims. The countries that decided on this kind of solution are Belgium ${ }^{16}$ A solution similar to that introduced in Belgium and France was also elaborated

\footnotetext{
${ }^{15}$ https://www.bfg.pl/przymusowa-restrukturyzacja/ochrona-wierzycieli/ (accessed on 14.11. 2017).

${ }^{16} \mathrm{https}: / /$ www.lexology.com/library/detail.aspx?g=7e92de45-cb8a-4a28-b7c5-4a1501f84e05 (accessed on 19.11.2017).
} 
Table 4. Types of subordination

\begin{tabular}{|l|l|}
\hline \multicolumn{1}{|c|}{ Type of subordination } & \multicolumn{1}{c|}{ Description } \\
\hline Contractual subordination & $\begin{array}{l}\text { It consists in including in the documentation of the instrument (e.g. } \\
\text { contract, prospectus) that the resulting liabilities are subordinated to } \\
\text { liabilities excluded from bail-in }\end{array}$ \\
\hline Statutory subordination & $\begin{array}{l}\text { It consists in the statutory introduction of a hierarchy of claims } \\
\text { (in which the liabilities resulting from the MREL requirement will } \\
\text { be included), which will absorb losses from liabilities excluded }\end{array}$ \\
\hline Structural subordination & $\begin{array}{l}\text { Refers to instruments issued by a resolution entity that has no } \\
\text { liabilities excluded from bail-in, which have the same or a lower } \\
\text { level of seniority than liabilities classified towards TLAC }\end{array}$ \\
\hline
\end{tabular}

Source: own work based on: FSB, Principles on Loss-absorbing and Recapitalisation Capacity of G-SIBs in Resolution Total Loss-absorbing Capacity (TLAC) Term Sheet, http://www.fsb.org/ wp-content/uploads/TLAC-Principles-and-Term-Sheet-for-publication-final.pdf (accessed on 17.11.2017).

by Spain $^{17}$, where two additional groups of claims have been implemented: Tier 3 capital and (absorbing losses on the next stage) the group of instruments analogous to the newly created class of claims in France, Belgium and Italy. Such a solution also involves drawbacks that have been pointed out for solutions implemented in the indicated countries.

A completely different approach has been applied in Germany ${ }^{18}$. It decided to subordinate the ordinary (unsecured) senior debt and German-specific Schuldscheine ${ }^{19}$ to other operational senior liabilities (e.g. unguaranteed deposits or structured securities). Such a solution means that (in the event of resolution or bankruptcy) liabilities that are essential for the further operating activity (and should not be burdened with losses to ensure the bank's stability and continuity of its functioning) have been separated from those whose main function is pure financing. Still, a large group of liabilities remains in one group of claims according to the hierarchy. That means that there is still a risk of breaking the pari passu and NCWO principles, although it has been shifted to further classes of seniority. In addition, this solution is inconsistent with the way which the European Commission (EC) plans

${ }^{17} \mathrm{https}: /$ www.bbva.com/en/government-approves-issuance-senior-non-preferred-debt-spain/ (accessed on 19.11.2017).

$18 \mathrm{https} / /$ www.rabobank.com/en/images/2015-05-position-paper-german-legislative-proposal-senior- unsecured-debt.pdf (accessed on 19.11.2017).

${ }^{19}$ Schuldschein is a security confirming the granting of a medium or long-term loan, the issuance of which is associated in Germany with much smaller administrative requirements than the issuance of standard corporate bonds. Schuldschein combines the features of loans and bonds. Schuldscheine are not securities in the sense of German law, which means that their issue does not require the preparation of a prospectus. Source: NordLB, The German Schuldscheindarlehen, https://www.nordlb.com/fileadmin/redaktion_en/analysen_prognosen/public_issuers/specials/2016/20160318_SSDSpecialFinaleng. pdf (accessed on 20.11.2017). 
Table 5. National solutions to the problem of liabilities subordination

\begin{tabular}{|c|c|c|c|c|c|c|}
\hline $\begin{array}{c}\text { Criterion } \\
\text { of comparison } \\
\end{array}$ & Belgium & France & Italy & Spain & Germany & Great Britain \\
\hline $\begin{array}{l}\text { The date } \\
\text { of adoption } \\
\text { of the legislation }\end{array}$ & 20 July 2017 & 10 December 2016 & $\begin{array}{l}\text { Work on legislation began } \\
\text { in November } 2017\end{array}$ & 23 June 2017 & $\begin{array}{l}\text { December } 2015 \\
\text { Work to create a non-preferred } \\
\text { senior debt is underway }\end{array}$ & $\begin{array}{l}\quad- \\
\text { Creation of non-preferred } \\
\text { senior debt is planned }\end{array}$ \\
\hline $\begin{array}{l}\text { Way of solving } \\
\text { the problem }\end{array}$ & $\begin{array}{l}\text { Creation of a new } \\
\text { subordination category } \\
\text { (senior non-preferred notes) }\end{array}$ & $\begin{array}{l}\text { Creation of a new } \\
\text { subordination category } \\
\text { (non-preferred debt) }\end{array}$ & $\begin{array}{l}\text { Creation of a new } \\
\text { subordination category } \\
\text { (non-preferred debt) and } \\
\text { making the corporate } \\
\text { deposits more senior }\end{array}$ & $\begin{array}{l}\text { Creation of a new } \\
\text { subordination } \\
\text { categories: Tier III and } \\
\text { non-preferred debt }\end{array}$ & $\begin{array}{l}\text { Subordination of ordinary senior } \\
\text { debt to other liabilities that had } \\
\text { had the same level of seniority } \\
\text { as the indicated liabilities before } \\
\text { the introduction of regulation; } \\
\text { Creation of non-preferred senior } \\
\text { debt - on a par with ordinary } \\
\text { debt and Schuldscheine is } \\
\text { planned }\end{array}$ & $\begin{array}{l}\text { Introduction of structural } \\
\text { subordination through the } \\
\text { creation of the separate } \\
\text { category for liabilities } \\
\text { resulting from the purchase of } \\
\text { an operating company's debt } \\
\text { by a holding company }\end{array}$ \\
\hline $\begin{array}{l}\text { The general } \\
\text { hierarchy of } \\
\text { privileged claims } \\
\text { (in the order of } \\
\text { covering losses)- } \\
\text { ultimately }\end{array}$ & $\begin{array}{l}\text { 1. CET1 } \\
\text { 2. AT1 } \\
\text { 3. T2 } \\
\text { 4. Senior non-preferred } \\
\text { notes } \\
\text { 5. Senior notes } \\
\text { 6. Retail / SME deposits } \\
\text { not covered by a deposit } \\
\text { guarantee scheme } \\
\text { 7. Guaranteed deposits }\end{array}$ & $\begin{array}{l}\text { 1. CET1 } \\
\text { 2. AT1 } \\
\text { 3. T2 } \\
\text { 4. Non-preferred senior } \\
\text { debt } \\
\text { 5. Other liabilities } \\
\text { 6. Retail / SME deposits } \\
\text { not covered by a deposit } \\
\text { guarantee scheme } \\
\text { 7. Guaranteed deposits }\end{array}$ & $\begin{array}{l}\text { 1. CET1 } \\
\text { 2. AT1 } \\
\text { 3. T2 } \\
\text { 4. Non-preferred senior } \\
\text { debt } \\
\text { 5. Other liabilities } \\
\text { 6. Corporate deposits } \\
\text { (from 2019) } \\
\text { 7. Retail / SME deposits } \\
\text { not covered by a deposit } \\
\text { guarantee scheme } \\
\text { 8. Guaranteed deposits }\end{array}$ & $\begin{array}{l}\text { 1. CET1 } \\
\text { 2. AT1 } \\
\text { 3. T2 } \\
\text { 4. T3 } \\
\text { 5. Non-preferred } \\
\text { senior debt } \\
\text { 6. Other liabilities } \\
\text { 7. Retail / SME } \\
\text { deposits not covered } \\
\text { by a deposit guarantee } \\
\text { scheme } \\
\text { 8. Guaranteed deposits }\end{array}$ & $\begin{array}{l}\text { 1. CET1 } \\
\text { 2. AT1 } \\
\text { 3. T2 } \\
\text { 4. Ordinary debt, Schuldscheine } \\
\text { and non-preferred senior debt } \\
\text { 5. Other liabilities } \\
\text { 6. Retail / SME deposits not } \\
\text { covered by a deposit guarantee } \\
\text { scheme } \\
\text { 7. Guaranteed deposits }\end{array}$ & $\begin{array}{l}\text { 1. CET1 } \\
\text { 2. AT1 } \\
\text { 3. T2 } \\
\text { 4. Debt purchased by the } \\
\text { holding company } \\
\text { 5. Non-preferred senior debt } \\
\text { 6. Other liabilities } \\
\text { 7. Retail / SME deposits not } \\
\text { covered by a deposit guarantee } \\
\text { scheme } \\
\text { 8. Guaranteed deposits }\end{array}$ \\
\hline Other remarks & $\begin{array}{l}\text { The previously issued } \\
\text { senior liabilities will be } \\
\text { included in group No. } 5\end{array}$ & $\begin{array}{l}\text { The previously issued } \\
\text { senior liabilities will be } \\
\text { included in group No. } 5\end{array}$ & - & - & - & $\begin{array}{l}\text { Approach results from } \\
\text { determining SPE as the } \\
\text { preferred resolution strategy }\end{array}$ \\
\hline
\end{tabular}

Source: own work based on: https://www.lexology.com/library/detail.aspx?g=7e92de45-cb8a-4a28-b7c5-4a1501f84e05; https://www.moodys.com/research/Moodys-New-senior-debt-instrument-in-France-will-modify-hierarchy--PR_359509; https://www.proshareng.com/news/Opinions\%20and\% 20Analysis/Non-Preferred-Senior-Will-Aid-EU-Bank-Resolution/37243; https:/www.db.com/ir/en/download/Moody_s_on_German_Italian_Banks_ 26_Jan_2016.pdf; https://www.bbva.com/en/government-approves-issuance-senior-non-preferred-debt-spain/; https://www.rabobank.com/en/images/2015-05-position-paper-german-legislative-proposal-senior-unsecured-debt.pdf; http://www.iflr.com/Article/3711810/Germany-explores-seniornon-preferred-debt-option.html; https://www.research.unicredit.eu/DocsKey/credit_docs_2017_159239.ashx?M= D\& R=45550097 and Bank of England, The Bank of England's approach to resolution; http://www.bankofengland.co.uk/financialstability/Documents/resolution/aproct17.pdf (accessed on 19.11.2017). 
to impose it on EU Member States. Germany will therefore be obliged to further modify the bankruptcy law. According to the reports, the EU requirements will be implemented by creating a new debt category with the same level of seniority as currently the ordinary senior debt (unsecured) and Schuldscheine ${ }^{20}$ have. That will further complicate the German hierarchy of claims.

The last European country in which the method of solving the problem of subordination has been determined is Great Britain (a similar approach is also used by Switzerland) ${ }^{21}$. It decided about the existence (after the categories of claims containing liabilities resulting from CET1, AT1 and T2) of the two debt preference groups. The first of them (i.e. absorbing losses after T2) is a group containing liabilities resulting from the debt purchased by the holding company. Thus, in the first place, bank losses will be covered by entities having a direct impact on the bank management. The second category whose creation is planned in the future, is a group that contains liabilities that meet the requirements to qualify them as eligible liabilities. However, after the indicated groups there will still be a category of claims which will include several types of obligations, which also means that the problem of pari passu and NCWO is only moved to the further categories in the hierarchy of claims.

In most EU countries the approach to subordination has not been shaped as yet.

\section{Directive amending the BRR Directive - Bank Creditor Hierarchy Directive ${ }^{22}$}

The problem of the interaction between the resolution and the principles of pari passu and NCWO was also noticed by the EC. It also observed the differentiation in the approaches of particular countries to solving the identified problem. However, due to the importance of the international character of banking activity and for the coherence of European law, it is necessary to develop one solution common for all EU countries. In addition, it is indicated that regulating the problem is necessary from the point of view of the common market ${ }^{23}$. In the opinion of the European Central Bank (ECB), harmonization of regulations is also particularly important from the

\footnotetext{
${ }^{20} \mathrm{http}: / / \mathrm{www}$. iflr.com/Article/3711810/Germany-explores-senior-non-preferred-debt-option.html (accessed on 19.11.2017).

${ }^{21}$ Bank of England, The Bank of England's approach to resolution, http://www.bankofengland. co.uk/financialstability/Documents/resolution/aproct17.pdf (accessed on 19.11.2017) oraz https:// www.research.unicredit.eu/DocsKey/credit_docs_2017_159239.ashx?M=D\&R=45550097 (accessed on 19.11.2017).

${ }^{22}$ Based on the compromise text of the Directive published on the EU legislative website on November 13, 2017. Source: http://eur-lex.europa.eu/legal-content/EN/TXT/PDF/?uri=CONSIL:ST_13723_2017_INIT\&from=EN (accessed on 15.11.2017).

${ }_{23}$ AFME, Proposal to amend bank creditor hierarchy, https://www.afme.eu/globalassets/downloads/consultation-responses/afme-prd-non-technical-paper-on-creditor-hierarchy-proposal.pdf (accessed on 17.11.2017).
} 
point of view of financial stability and the possibility of the effective application of bail-in during resolution ${ }^{24}$. From the banks' point of view, unifying the rules will help them build an appropriate buffer of liabilities that can absorb potential losses, thereby strengthening the credibility of resolution actions ${ }^{25}$.

For that reason, in November 2016 the EC announced a proposal for a directive that would amend the BRR Directive (among practitioners the proposal is called the Bank Creditor Hierarchy Directive, BCHD) ${ }^{26}$. BCHD entered into force on 28 December 2017.

The Directive provides for the creation in each Member State of a new category of claims that would be senior to own funds instruments and subordinated debt not included in own funds, but junior to ordinary or preferred senior debt. The new preference category would include the non-preferred senior debt. This category would embrace debt instruments newly issued by banks that meet the conditions for including them in eligible liabilities, i.e.:

- Maturity of at least one year,

- Not containing the derivatives or not being derivatives itself,

- Issuance documents (e.g. a prospectus) clearly indicate that these instruments have a lower level of seniority (than the usual senior liabilities).

If the introduced changes resulted in the division of the previous category of claims into two or more groups in which the lowest level of seniority has a category which includes instruments meeting the requirements set by the directive, then these countries may be considered as compatible with the new Directive. Member States that have implemented modifications in the hierarchy of claims between 31 December 2016 and the date of entry into force of the proposed directive should not apply the provisions unless they are similar to those of the BCHD.

Countries are required to implement the directive by 1 January 2019.

\section{Conclusion}

The sources of financing banking operations are characterized by considerable differentiation. This is reflected not only in the diversity of their forms (instruments of ownership, debt instruments, etc.), but also in the different level of risk that is embedded in the mechanisms for covering potential bank losses by investors. An additional factor increasing the level of complexity in the ranking of the sources

\footnotetext{
${ }^{24}$ European Central Bank, Opinion of the European Central Bank of 8 March 2017 on a proposal for a directive of the European Parliament and of the Council on amending Directive 2014/59/EU as regards the ranking of unsecured debt instruments in insolvency hierarchy, CON/2017/6, p. 2.

${ }^{25}$ AFME, Proposal to amend....

${ }^{26}$ Proposal for a DIRECTIVE OF THE EUROPEAN PARLIAMENT AND OF THE COUNCIL on amending Directive 2014/59/EU of the European Parliament and of the Council as regards the ranking of unsecured debt instruments in insolvency hierarchy [first reading] - Confirmation of the final compromise text with a view to agreement, 13724/17
} 
of banks financing in terms of their financial accountability for bank losses is the overlapping between the supervisory notions of capital adequacy and the concepts from business and bankruptcy law.

As a result there is a number of situations in which the order of covering losses according to particular approaches (resulting from the law regarding the activity of companies and cooperatives, from the bankruptcy law, from the scope of banking supervision) does not coincide. This generates the risk of the unequal treatment of bank creditors, at least incompliant with applicable bankruptcy law. This is particularly important in the case of intervention measures. Breaking the rules of pari passu and NCWO may be connected with complaints from the injured parties and the necessity to pay them compensation. This adversely affects the perception of the supervisory and resolution activities by the public, and, consequently, may weaken the effectiveness of interventions towards banks.

As a consequence, the countries decided to introduce their own methods of solving the indicated problem to improve the bank resolution and bankruptcy activities. However, this has led to significant differences between EU Member States. This is also unfavorable from the point of view of investors who, when deciding to purchase securities issued in a given country, must always verify how the hierarchy of claims has been defined in the respective national law. For that reason, the actions taken by the EC should be assessed as positive. Nevertheless, it is worth noting that as a result, the hierarchy of bank claims will be additionally complicated.

Bearing in mind that from the point of view of the supervision and resolution authorities, it is important to ensure banks' ability to absorb losses at the stage of normal operations and in the event of bankruptcy, it seems that it would be possible to significantly streamline the hierarchy of claims (which would also require the simplification of regulations in the field of capital adequacy).

First, own funds classified as CET1 and AT1, as performing the same function, could be combined into one group and constitute the first (one) category of capital and subordination - own funds for the ongoing activity (going concern own funds).

Second, the idea of creating a T2 capital and eligible liabilities is to ensure the ability to cover losses in the event of bankruptcy. Therefore, these liabilities could also create one supervisory category and one in the hierarchy of claims - funds securing the coverage of the costs of possible bankruptcy (gone concern capacity).

In each of the proposed funds' categories, the number of accepted securities should be as low as possible to limit potential difficulties resulting from the varied profile and status of the instruments.

The other forms of bank financing should be analyzed and included in the hierarchy of claims in such a way that two groups are formed: one covering other liabilities (not related to going concern own funds and gone concern capacity), whose aim is only to obtain funds for financing the operations of banks, and the second (more senior) covering liabilities that are essential for maintaining the operational continuity of the bank (e.g. liabilities resulting from hedging transactions or deposits not covered 
by guarantees). Such a structure would allow for a significant simplification of the issues related to the capital adequacy of banks and the hierarchy of claims.

\section{Bibliography}

AFME, Proposal to amend bank creditor hierarchy, https:/www.afme.eu/globalassets/downloads/consultation-responses/afme-prd-non-technical-paper-on-creditor-hierarchy-proposal.pdf (accessed on 17.11.2017).

Annex 3 - Insolvency Ranking in the jurisdictions of the Banking Union, https://srb.europa.eu/sites/srbsite/files/ldr_-_annex_on_insolvency_ranking_13_02_2017_final.pdf (accessed on 15.11.2017).

Bank of England, The Bank of England's approach to resolution, http:/www.bankofengland.co.uk/ financialstability/Documents/resolution/aproct17.pdf (accessed on 19.11.2017).

Czapiewski P., 2012, Organizacja emisji akcji [Organization of shares issuance], [w:] M.S. Wiatr (ed.), Bankowość korporacyjna [Corporate banking], Difin, Warszawa.

Czapiewski P., 2012, Sekurytyzacja aktywów [Asset securutization], [w:] M.S. Wiatr (ed.), Bankowość korporacyjna [Corporate banking], Difin, Warszawa

Czapiewski P., 2013, Obligacje - rodzaje, rentowność i ryzyko [Bonds-kinds, profitability and risk] [w:] P. Niedziółka (ed.), Oszczędzam i inwestuję [Saving and investing], Wydawnictwo Naukowe ePrzedsiębiorczość, Gniezno.

Directive 2014/59/Eu of the European Parliament and of the Council of 15 May 2014 establishing a framework for the recovery and resolution of credit institutions and investment firms and amending Council Directive 82/891/EEC, and Directives 2001/24/EC, 2002/47/EC, 2004/25/EC, 2005/56/EC, 2007/36/EC, 2011/35/EU, 2012/30/EU and 2013/36/EU, and Regulations (EU) No $1093 / 2010$ and (EU) No 648/2012, of the European Parliament and of the Council.

EBA, 2016 EU-Wide Stress Test, http://www.eba.europa.eu/documents/10180/1532819/2016-EUwide-stress-test-Results.pdf (accessed on 13.11.2017).

European Banking Federation, European Banking Sector Facts \& Figures 2015, http://www.zyyne. $\mathrm{com} / \mathrm{zh} 5 / 187540 \# \mathrm{p}=14$ (accessed on 15.11.2017).

European Central Bank, Opinion of the European Central Bank of 8 March 2017 on a proposal for a directive of the European Parliament and of the Council on amending Directive 2014/59/EU as regards the ranking of unsecured debt instruments in insolvency hierarchy, CON/2017/6

FSB, Principles on Loss-absorbing and Recapitalisation Capacity of G-SIBs in Resolution Total Loss-absorbing Capacity (TLAC) Term Sheet, http://www.fsb.org/wp-content/uploads/TLAC-Principles-and-Term-Sheet-for-publication-final.pdf (accessed on 17.11.2017)

Gospodarowicz M., 2015, System gwarantowania depozytów z uwzględnieniem ryzyka banku i ryzyka systemowego [Deposit guarantee systems taking into account bank risk and systemic risk], Oficyna Wydawnicza SGH, Warszawa

https:/www.bbva.com/en/government-approves-issuance-senior-non-preferred-debt-spain/ (accessed on 19.11.2017).

https://www.bfg.pl/przymusowa-restrukturyzacja/ochrona-wierzycieli/ (accessed on 14.11.2017).

https://data.worldbank.org/indicator/FB.BNK.CAPA.ZS?end=2016\&start=2010 (accessed on 14.11. 2017).

https://www.db.com/ir/en/download/Moody_s_on_German_Italian_Banks_26_Jan_2016.pdf (accessed on 19.11.2017).

http://www.eba.europa.eu/regulation-and-policy/own-funds (accessed on 14.11.2017).

http:/eur-lex.europa.eu/legal-content/EN/TXT/PDF/?uri=CONSIL:ST_13723_2017_INIT\&from=EN (accessed on 15.11.2017). 
http://www.iflr.com/Article/3711810/Germany-explores-senior-non-preferred-debt-option.html (accessed on 19.11.2017).

https://www.lexology.com/library/detail.aspx?g=7e92de45-cb8a-4a28-b7c5-4a1501f84e05 (accessed on 19.11.2017).

https://www.moodys.com/research/Moodys-New-senior-debt-instrument-in-France-will-modify-hierarchy--PR 359509 (accessed on 19.11.2017).

https://www.proshareng.com/news/Opinions\%20and\%20Analysis/Non-Preferred-Senior-Will-AidEU-Bank-Resolution/37243 (accessed on 19.11.2017).

https://www.rabobank.com/en/images/2015-05-position-paper-german-legislative-proposal-senior-unsecured-debt.pdf (accessed on 19.11.2017).

https://www.research.unicredit.eu/DocsKey/credit_docs_2017_159239.ashx?M=D\&R=45550097 (accessed on 19.11.2017).

Kerlin J., 2016, Ewolucja roli instytucji gwarantujacych depozyty w sieci bezpieczeństwa finansowego unii europejskie [The evolution of deposit guarantee schemes in the European Union's financial safety nets], Oficyna Wydawnicza SGH, Warszawa.

Koleśnik J., 2013, Nowa Umowa Kapitałowa [New Capital Accord], [w:] M. Zaleska (red.), Bankowość [Banking], C.H. Beck, Warszawa.

Koleśnik J., 2014, Adekwatność kapitałowa banków. Standardy regulacyjne [Banks' capital adequacy. Regulatory standards], Difin, Warszawa.

Koleśnik J., 2014, Przeregulowanie działalności bankowej w Unii Europejskiej [Overregulation of the banking activity in the European Union], Studia Ekonomiczne, nr 186, Uniwersytet Ekonomiczny w Katowicach.

Koleśnik J., 2015, Jednolity mechanizm restrukturyzacji i uporzadkowanej likwidacji [Single resolution mechanism], [w:] M. Zaleska (ed.), Europejska unia bankowa [European banking union], Difin, Warszawa.

Koleśnik J., 2017, Bank Recovery and Resolution Mechanisms in non-Banking Union Countries, [w:] Z. Korzeb (ed.), Comparative Analysis of the Conditions of Banking Operation Inside and Outside the Euro Area, Delta Publicaciones, Madrid.

Machowska A. (ed.), 2016, Prawo restrukturyzacyjne i upadłościowe. Zagadnienia praktyczne [Restructuring and bankruptcy law. Practical issues], Wolters Kluwer, Warszawa

Niedziółka P., 2002, Zarządzanie portfelem papierów wartościowych na zlecenie [Management of securities' portfolio on commission], [w:] J. Nowakowski, J. Mieloszyk, P. Niedziółka (ed.), Portfel Inwestycyjny banku - konstrukcja i zarządzanie portfelem papierów wartościowych [Bank investment portfolio - construction and management of securities'portfolio], Difin, Warszawa

Nord LB, The German Schuldscheindarlehen, https://www.nordlb.com/fileadmin/redaktion en/analysen_prognosen/public_issuers/specials/2016/20160318_SSDSpecialFinaleng.pdf (accessed on 20.11.2017).

Nowakowski J., Famulska T., 2008, Stabilność i bezpieczeństwo systemu bankowego [Stability and safety of banking system], Difin, Warszawa.

Orzechowski A., Czy inwestorzy w Polsce sa wynagradzani za ponoszenie ryzyka systematycznego? Test empiryczny modelu CAPM [Are the investors rewarded for taking systematic risk? Empirical test of CAPM model], [w:] R. Bartkowiak, J. Ostaszewski (red.), Dorobek ekonomii, finansów i nauk o zarzadzaniu oraz jego praktyczne wykorzystanie na przełomie XX $i$ XXI wieku [Achievement of economy, finance and management sciences and its practical use at the turn of the XX and XXI century], Oficyna Wydawnicza SGH, Warszawa 2012.

Proposal for a Directive Of The European Parliament And Of The Council on amending Directive 2014/59/EU of the European Parliament and of the Council as regards the ranking of unsecured debt instruments in insolvency hierarchy.

Proposal for a Directive of the European Parliament and of the Council on amending Directive 2014/59/ EU of the European Parliament and of the Council as regards the ranking of unsecured debt in- 
struments in insolvency hierarchy [first reading] - Confirmation of the final compromise text with a view to agreement, 13724/17.

Proposal for A Directive of the European Parliament and of the Council amending Directive 2014/59/ EU on loss-absorbing and recapitalisation capacity of credit institutions and investment firms and amending Directive 98/26/EC, Directive 2002/47/EC, Directive 2012/30/EU, Directive 2011/35/ EU, Directive 2005/56/EC, Directive 2004/25/EC and Directive 2007/36/EC

Regulation (EU) no. 575/2013 of the European Parliament and of the Council of 26 June 2013 on prudential requirements for credit institutions and investment firms, amending Regulation (EU) no. $648 / 2012$.

Ślązak E., 2011, Efektywność transformacji terminów kapitalu przez banki [Effectiveness of capital's maturity transformation by banks], [w:] A. Gospodarowicz (red.), Finanse. Nowe wyzwania teorii i praktyki. Bankowość [Finances. New challenges of theory and practice. Banking], Prace Naukowe Uniwersytetu Ekonomicznego we Wrocławiu, Wrocław.

Ślązak E., 2015, Idiosynkratyczne funkcje banku - ujęcie teoretyczno-praktyczne [Idiosyncratic bank functions - theoretical and practical approach], Oficyna Wydawnicza SGH, Warszawa.

Statistical Data Warehouse, European Central Bank (accessed on 17.11.2017).

Szczepańska O., 2015, MREL and TLAC i.e. how to increase the loss absorption capacity of banks, Bezpieczny Bank 3(60).

Ustawa z dnia 28 lutego 2003 r. Prawo upadłościowe [Bankruptcy law] (Dz.U.2016.2171 z późniejszymi zmianami).

Zaleska M., 2016, Ryzyko bankowe - zmiany w sektorze bankowym Unii Europejskiej [Bank riskchanges in the banking sector of the European Union], [w:] T. Czerwińska, K. Jajuga (red.), Ryzyko instytucji finansowych - wspólczesne trendy $i$ wyzwania [Financial institutions' risk - modern trends and challenges], Wydawnictwo Beck, Warszawa.

\section{STRUKTURA PASYWNEJ STRONY BILANSU BANKU A ZASADA RÓWNEGO TRAKTOWANIA I NIEPOGARSZANIA SYTUACJI WIERZYCIELI}

Streszczenie: Pasywna strona bilansu banków charakteryzuje się znacznym zróżnicowaniem. Intencją nadzorców jest, aby straty banków pokrywane były zgodnie z określoną kolejnością, która przewiduje, iż pierwsi narażeni są na nie właściciele, a w dalszej kolejności wierzyciele. Kolejność pokrywania strat według regulacji nadzorczych jest często rozbieżna z kolejnością wynikającą z hierarchii uprzywilejowania wierzytelności. W takiej sytuacji podjęcie działań może wiązać się ze złamaniem podstawowych zasad obowiązujących w prawie upadłościowym i resolution: zasady pari passu oraz no-creditor-worse-off. Celem artykułu jest identyfikacja sytuacji, w których dochodzi do złamania wskazanych zasad, a także przegląd i ocena rozwiązań krajowych, które zostały wdrożone w celu zapewnienia przestrzegania reguł prawa upadłościowego.

Słowa kluczowe: kapitały banku, fundusze własne, pari passu, no-creditor-worse-off, hierarchia uprzywilejowania wierzytelności. 